\title{
Research on RCC and Timber Multi-Storey Structures using Response Spectrum Search
}

\author{
Shubham Bhutada, P.D. Pachpor, A.K. Sharma
}

\begin{abstract}
The sustainability of Reinforced Cement Concrete material and its structures will play predominant role in creating environmental impacts. The alternative material for construction of multi-story structures is the need of hour. The substitute material should be compatible for construction as well as should sustained the seismic forces during earthquake. The substitute material taken is Timber, being an orthogonal in nature, behaves differently from $R C C$ with respect to elastic and physical properties. Here, two geometrically identical multi-story structures are compared to find the seismic compatibility of timber structure as compared to RCC structure. Both the buildings were modelled in ETABS software using different material properties, viz. RCC and Timber, and were analysed using Response Spectrum Analysis. Different parameters were studied and compared for both the buildings like, shear force, bending moment, lateral story displacement and story shear. After analysis, it was concluded that timber structures can be built with lighter sections as that of RCC. And due to much more flexibility of Timber Structures, proper design of connections and their adequate strength is required to increase the stiffness of timber structures.
\end{abstract}

Keywords - RCC, Response Spectrum, Seismic Performance, Story Displacement, Story Shear, Timber

\section{INTRODUCTION}

Concrete is a material that literally holds different places together. From row houses and apartment buildings to bridges, viaducts and sidewalks, this inescapable grey material's importance to modern urban life is undeniable. Despite of its undeniable importance in day-to-day construction purpose, many research scholars, environmentalists and construction engineers are seeking for a complete alternate material to $\mathrm{RCC}$, due to increasing amount of severe harmful environmental impact of material. There are however a number of alternative green building materials that offer alternatives to concrete, and a lower environmental impact. And one of those alternative material is Wood or Timber.

Timber still retains many advantages over more industrial building materials like concrete or steel. Not only do trees absorb $\mathrm{CO}_{2}$ as they grow, they also require much less energy consumption methods to process into construction products.

Revised Manuscript Received on July 10, 2019.

Shubham Bhutada, P.G. Student, Structural Engineering, Shri Ramdeobaba College of Engineering and Management, Nagpur. India (Email: shubham.bhutada34@gmail.com)

Dr. P.D. Pachpor, Professor, Civil Engineering, Shri Ramdeobaba College of Engineering and Management, Nagpur. India (E-mail: pachporpd@rknec.edu)

Dr. A.K. Sharma, Associate Professor, Civil Engineering, Shri Ramdeobaba College of Engineering and Management, Nagpur. India (Email:sharmaak@rknec.edu)
Properly managed forests are also renewable and can ensure a biodiverse habitat. In recent years, there has been a tremendous increase in the construction of multi-storey building using timber. This is due to several of reasons like quick construction process, reduced man made safety hazards at construction site, the capacity of storing carbon dioxide by displacing it from the atmosphere and reducing energy consumption during the production, transportation and erection compared to other construction materials, and last but not the least the good thermal properties of wood which, together with insulation materials, easily lead to excellent rates in the energy performance of overall building. These benefits of timber, along with the up to the mark seismic performance as demonstrated by different researchers in their recent research results based on numerical simulations and shake table tests on multi-storey buildings, gives the clear explanation of why timber is being getting replaced by other materials like RCC, steel, masonry or composite, mainly in the field of residential and educational constructions. However apart from these material properties, there are also several other technical and legislative reasons.

Aim of the thesis work is high strength and efficient performance of multi-story structure using Alternative Material to RCC.

Following are the objectives of the thesis:

i. To present the construction material that would replace RCC in utmost aspects.

ii. To obtain the serviceable and safer structure.

iii. To restrict the large amount of consumption of reinforcing steel and concrete.

\section{METHODOLOGY AND MODELLING}

This section of the thesis presents the methodology for the dynamic analysis of both the structures, viz. Reinforced Cement Concrete and Timber, which are to be compared. A detailed modelling and analysis of both the structures is carried out on ETABS software. ETABS computer program is used for the analysis as well as design purpose. The program is specialized for the linear static and dynamic analysis of multi-story structures. A three dimensional mathematical model was prepared for each of the two buildings under comparison. All columns, beams and structural slabs were included in the model of each

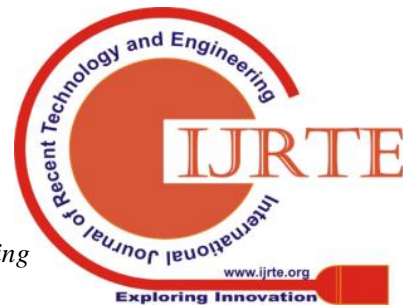


modelling. The reinforced concrete structural elements are assumed not to be cracked and the steel reinforcements were ignored, which is the customary way of modelling reinforced concrete buildings for dynamic analysis. As well as timber structures are modelled as beam-column structure and the slab panels, which are used as roof, are made up of different wood products like plywood or OSB, but P5 or P7 particleboard may also be used. And the intermediate floor consists of solid timber joists and plasterboard decking, which comprises different layers of resilient material, sound insulation and thermal insulation.

The need of replacement of conventional RCC construction by Timber construction is due to several reasons like:

i. Cement Production results in high levels of $\mathrm{CO}_{2}$ output from cement industries. These production is the world's third most producer of anthropogenic $\mathrm{CO}_{2}$, after transport and energy generation. It causes nearly $4-5 \%$ of worldwide total of $\mathrm{CO}_{2}$ emissions caused by cement production.

ii. Over a decade, due to increase in construction of buildings and many other RCC structures like dams, bridges, water tanks, etc. in India, the demand of structural steel will outpaced the supply sector. Then it will be the necessity for us to import the structural steel from other countries, just to fulfil the demand of our construction industries.

Despite of several reasons behind the replacement of RCC construction, there are several advantages of using Timber as a structural timber, which are as follows:

i. Timber has a relatively high strength-to-weight ratio compared with other materials, producing light weight structures which require lighter foundations and make them particularly suitable for brownfield developments.

ii. Timber displaces $\mathrm{CO}_{2}$ from the atmosphere by storing it in itself, and also reduces the energy consumption during the production, transportation and erection of structural components as compared to other construction materials.

According to IS: 3629 - 1986, different timber species are defined depending of their strength characteristics, durability and treatability of material. As per EUROCODE 5, different types of structural timber are Solid Hardwood, Solid Softwood, Glulam, LVL, PSL, LSL, Plywood, OSB, Particleboard, and Hardboard. The average life of timber material is considered to be from 60 months to 1220 months, depending on their heartwood durability.

The construction of timber structure is very simple and convenient for an experienced engineer and a team of skilled labour. Those natural log of timber should be sharply and finely cut out to required cross-section as per drawings. And the framing materials and sections must be well treated with preservatives so as not to get deteriorated in future. These sections required very strong connections to sustain the serviceability and safety of structure in any seismic activity. There are different types of connections required in these timber structure, which are as follows:

a) U-shaped steel clip -
This steel clip is generally used to provide beam-to-beam connection using bolts passed through the holes of clip on the other side of timber frame beam, as shown in fig. 1 .

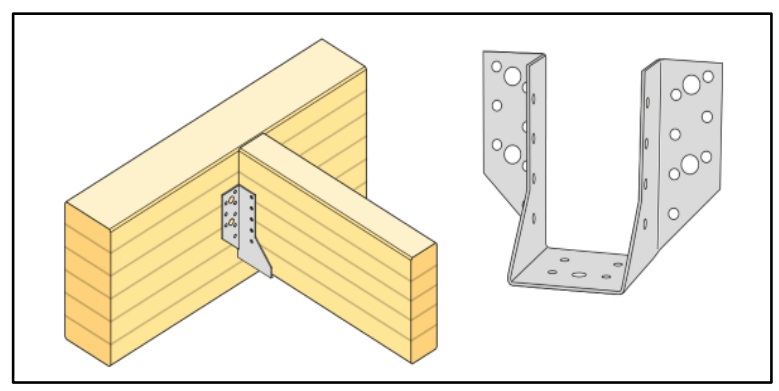

Fig.1 U-shaped Steel Clip Connector

\section{b) Beam-Column Connector-}

This steel plate is used for connection between beam and column at Beam-Column joint. It is also bolted through-out the column cross-section using long bolts with high strength, so as to provide better stability at the joint in the whole structure, as shown in fig. 2 .

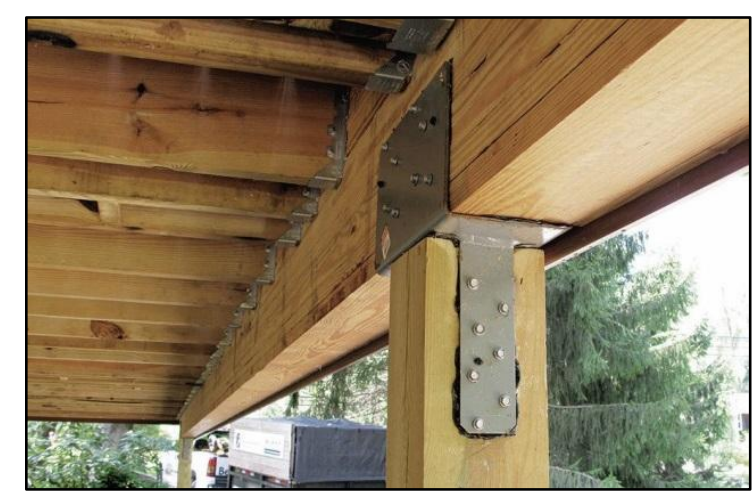

Fig.2 Beam-Column Connector

These two are the main connectors used in the whole structure. But other than these two, one more connector is used at the column base, which is either Knife Plate connector or Stirrup Bracket connector. These are connected at the base of the timber column by providing the slit cut in the middle of column base and fixing a steel plate inside it. These is used to keep the timber column at some height above from the ground surface so as not to get in contact with the ground soil. And also it is used at the base of each floor, to fix the new timber column of height equal to floor height.

In this paper, two multi-storey $\mathrm{G}+3$ structures are modelled using ETABS software and are analysed under response spectrum function, as per IS: 1893 (Part I) - 2016. One structure is modelled using timber material and another structure with RCC material. Then, both the structures were compared under dynamic conditions using different parameters like Lateral Story Displacement, Story Shear, Shear Force and Bending Moment. Both the models are geometrically symmetrical. The description of both the buildings is identical in all aspects except the material property. 
The material property for both RCC and Timber are very different. RCC is considered to be an isotropic material, while timber is an orthotropic material. The material property data (which is to be given as input in ETABS software) is given below in the table for both RCC as well as Timber.

Table.1 Material Property Data for RCC

\begin{tabular}{|c|c|}
\hline Property & Value \\
\hline Mass Density & $2548.54 \mathrm{~kg} / \mathrm{m}^{3}$ \\
\hline Modulus of Elasticity (E) & $25000 \mathrm{MPa}$ \\
\hline Poisson's Ratio (U) & 0.2 \\
\hline Shear Modulus (G) & $10416.67 \mathrm{MPa}$ \\
\hline $\begin{array}{c}\text { Coefficient of Thermal } \\
\text { Expansion (A) }\end{array}$ & $0.0000055 /{ }^{\circ} \mathrm{C}$ \\
\hline
\end{tabular}

Table.2 Material Property Data for Timber (Spruce) (From Wood Handbook ${ }^{[5]}$ )

\begin{tabular}{|c|c|}
\hline Property & Value \\
\hline Mass Density & $400 \mathrm{~kg} / \mathrm{m}^{3}$ \\
\hline $\mathrm{E}_{1} / \mathrm{E}_{\mathrm{L}}$ & $8500 \mathrm{MPa}$ \\
\hline $\mathrm{E}_{2} / \mathrm{E}_{\mathrm{T}}$ & $663 \mathrm{MPa}$ \\
\hline $\mathrm{E}_{3} / \mathrm{E}_{\mathrm{R}}$ & $365.5 \mathrm{MPa}$ \\
\hline $\mathrm{G}_{12}$ & $544 \mathrm{MPa}$ \\
\hline $\mathrm{G}_{13}$ & $518.5 \mathrm{MPa}$ \\
\hline $\mathrm{G}_{23}$ & $25.5 \mathrm{MPa}$ \\
\hline $\mathrm{A}_{1}$ & $0.0000038 /{ }^{\circ} \mathrm{C}$ \\
\hline $\mathrm{A}_{2}$ & $0.0000219 /{ }^{\circ} \mathrm{C}$ \\
\hline $\mathrm{A}_{3}$ & $0.0000304 /{ }^{\circ} \mathrm{C}$ \\
\hline $\mathrm{U}_{12}$ & 0.372 \\
\hline $\mathrm{U}_{13}$ & 0.467 \\
\hline $\mathrm{U}_{23}$ & 0.435 \\
\hline
\end{tabular}

Following is the description of the building used for modelling of both the structures in ETABS:

Description of RCC structure:

- Number of Story: 4

- Height of each floor: $3.0 \mathrm{~m}$

- Total height of building: $12.0 \mathrm{~m} \Phi$

- Plan dimension: $7.0 \mathrm{~m}$ x $13.0 \mathrm{~m}$

- Floor thickness: $0.125 \mathrm{~m}$

- Comp. strength of concrete, $\mathrm{f}_{\mathrm{ck}}=25 \mathrm{~N} / \mathrm{mm}^{2}$

- The steel used, $\mathrm{Fe}=500 \mathrm{~N} / \mathrm{mm} 2$

- Density of concrete: $25 \mathrm{kN} / \mathrm{m}^{3}$

- Poisson's Ratio: 0.15

- Size of column: $300 \mathrm{~mm}$ x $300 \mathrm{~mm}$

- Size of beam: $230 \mathrm{~mm}$ x $450 \mathrm{~mm}$

- Moderate seismic zone: (III)

- Live load on each story: $2 \mathrm{kN} / \mathrm{m}^{2}$

- The floor finish load is: $1.50 \mathrm{kN} / \mathrm{m}^{2}$

- Column base are considered to be fixed at $2.0 \mathrm{~m}$ below ground level.

Description of Timber structure:

- Number of Story: 4

- Height of each floor: $3.0 \mathrm{~m}$

- Total height of building: $12.0 \mathrm{~m}$

- Plan dimension: $7.0 \mathrm{~m}$ x $13.0 \mathrm{~m}$

- Floor thickness: $0.125 \mathrm{~m}$

- Density of timber: $3.923 \mathrm{kN} / \mathrm{m}^{3}$
- Poisson's Ratio: 0.4

- Size of column: $300 \mathrm{~mm}$ x $300 \mathrm{~mm}$

- Size of beam: $230 \mathrm{~mm}$ x $450 \mathrm{~mm}$

- Moderate seismic zone: (III)

- Live load on each story: $2 \mathrm{kN} / \mathrm{m}^{2}$

- The floor finish load is: $1.50 \mathrm{kN} / \mathrm{m}^{2}$

- Column base are considered to be fixed at $2.0 \mathrm{~m}$ below ground level.

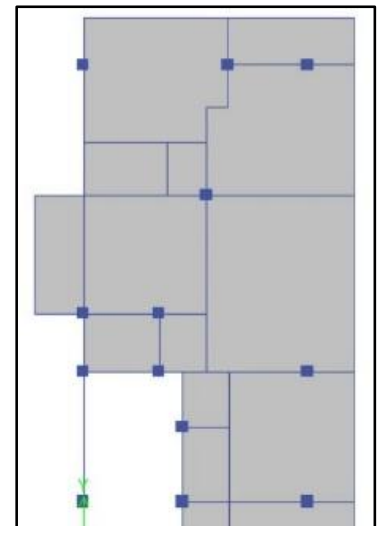

Fig.3 Floor plan of Building from ETABS

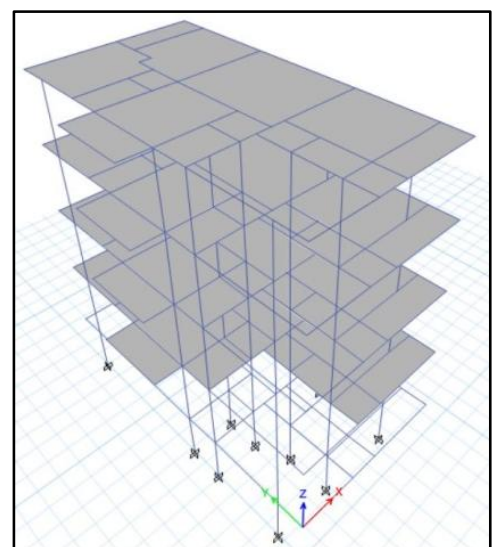

Fig.4 3-D View of Building from ETABS

\section{OBSERVATIONS AND RESULTS}

The present work attempts to study the behaviour of G+3 bare frame buildings with fixed support. Framed structure of RCC \& Timber material sections have been considered. This both the buildings are analysed for seismic forces considered in Zone-III, Importance Factor of 1.0 and Response Reduction Factor of 3.0 for both the bare frame buildings. Analysis is done in ETABS and the parametric results like Bending Moment, Shear Force, Lateral Story Displacement, Story Shear, Modal Period and Base Reactions, i.e., Seismic Weight of Building are graphically shown below.

\section{i. Shear Force and Bending Moment :}

While comparing the same beam in both the structures, it was found out that the timber structure can withstand the seismic forces even in lighter cross-sections, as shown in table below. 
Table 3. S.F. \& B.M. in Beam B64 @ $1^{\text {st }}$ floor

\begin{tabular}{|c|c|c|}
\hline Material & S.F. $(\mathrm{kN})$ & B.M. $(\mathrm{kN} . \mathrm{m})$ \\
\hline RCC & 55.0787 & 51.1545 \\
\hline Timber & 25.0787 & 24.6708 \\
\hline
\end{tabular}

Table 4. S.F. \& B.M. in Column C12 @ $1^{\text {st }}$ floor

\begin{tabular}{|c|c|c|}
\hline Material & S.F. $(\mathrm{kN})$ & B.M. $(\mathrm{kN} . \mathrm{m})$ \\
\hline RCC & 1.0767 & 2.5185 \\
\hline Timber & 0.6858 & 1.5441 \\
\hline
\end{tabular}

Therefore, the values of shear force and bending moment in RCC as well as Timber Structure are varying by nearly half of their value, provided both beams and columns are of same cross-section. It concludes that timber structure will satisfactorily behave under lesser cross-section than provided in the current model. Thus, all the beam sections in Timber structure will get reduced in size and will result in the reduction of seismic weight of the building by a significant amount.

\section{ii. Lateral Story Displacement:}

The displacement of each structure was computed for response spectrum case in both the direction denoted by SPEC-X and SPEC-Y, and the values are tabulated below.

Table 5. Story Displacement in SPEC-X

\begin{tabular}{|c|c|c|c|}
\hline \multirow{2}{*}{ Story } & \multirow{2}{*}{ Elevation $(\mathrm{m})$} & \multicolumn{2}{|c|}{ X-direction $(\mathrm{mm})$} \\
\cline { 3 - 4 } & & Timber & RCC \\
\hline Terrace & 12 & 25.919 & 20.85 \\
\hline $3^{\text {rd }}$ & 9 & 22.698 & 18.405 \\
\hline $2^{\text {nd }}$ & 6 & 17.694 & 14.348 \\
\hline $1^{\text {st }}$ & 3 & 11.059 & 8.948 \\
\hline Plinth & 0 & 3.273 & 2.65 \\
\hline Base & -2 & 0 & 0 \\
\hline
\end{tabular}

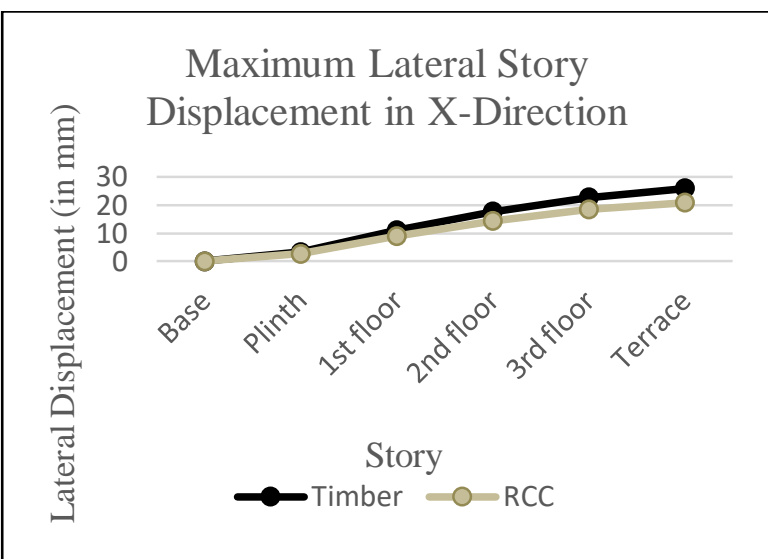

Fig.5 Graphical Comparison for Storey Displacement in X-direction

Table 6. Story Displacement in Spec-Y

\begin{tabular}{|c|c|c|c|}
\hline \multirow{2}{*}{ Story } & \multirow{2}{*}{ Elevation $(\mathrm{m})$} & \multicolumn{2}{|c|}{ Y-Direction $(\mathrm{mm})$} \\
\cline { 3 - 4 } & & Timber & RCC \\
\hline Terrace & 12 & 18.597 & 14.291 \\
\hline $3^{\text {rd }}$ & 9 & 16.042 & 12.474 \\
\hline $2^{\text {nd }}$ & 6 & 12.179 & 9.508 \\
\hline $1^{\text {st }}$ & 3 & 7.195 & 5.644 \\
\hline Plinth & 0 & 1.735 & 1.46 \\
\hline Base & -2 & 0 & 0 \\
\hline
\end{tabular}

Maximum Lateral Story Displacement in Y-Direction
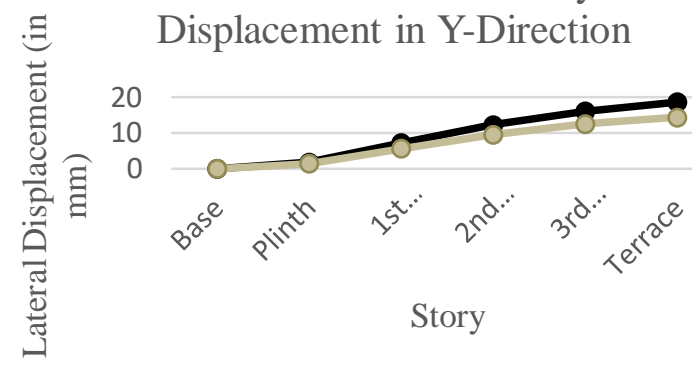

$\longrightarrow$ Timber $\mathrm{RCC}$

Fig.6 Graphical Comparison for Storey Displacement in Y-direction

From the above tabulated values, it is seen that displacement is comparatively more in Timber structure than in RCC structure. This displacement of timber structure is due to their more flexibility. This flexibility can also be reduced by proper design of high-strength connections at each joint in whole structure.

iii. Story Shear:

Here, the seismic forces obtained due to response spectrum are applied on the structure in both $\mathrm{X}$ and $\mathrm{Y}$ direction, viz. SPEC-X and SPEC-Y, and the values are graphically shown below in fig. $7 \& 8$.

Table 7. Story Shear in Spec-X direction

\begin{tabular}{|c|c|c|c|}
\hline \multirow{2}{*}{ Story } & \multirow{2}{*}{$\begin{array}{c}\text { Elevation } \\
(\mathrm{m})\end{array}$} & \multicolumn{2}{|c|}{ X-direction $(\mathrm{mm})$} \\
\cline { 3 - 4 } & 12 & Timber & RCC \\
\hline Terrace & 24.80 & 75.82 \\
\hline $3^{\text {rd }}$ & 9 & 42.73 & 131.58 \\
\hline $2^{\text {nd }}$ & 6 & 55.62 & 171.77 \\
\hline $1^{\text {st }}$ & 3 & 65.57 & 202.11 \\
\hline Plinth & 0 & 66.20 & 206.03 \\
\hline
\end{tabular}

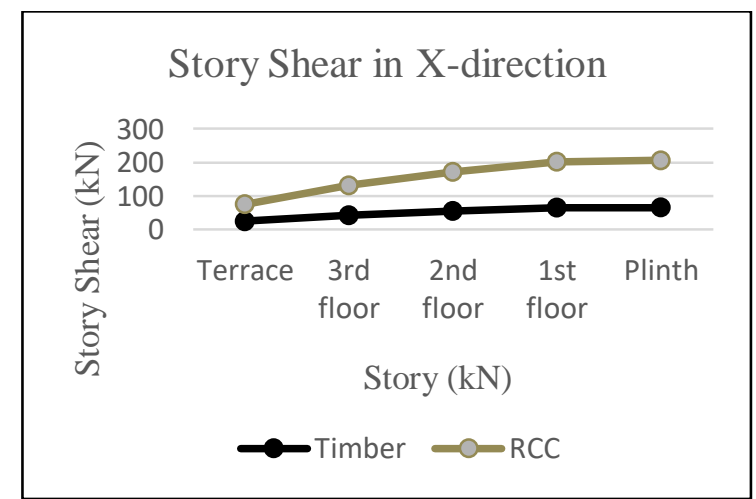

Fig.7 Graphical Comparison for Story Shear in X direction 
Table 8. Story Shear in Spec-Y direction

\begin{tabular}{|c|c|c|c|}
\hline \multirow{2}{*}{ Story } & \multirow{2}{*}{$\begin{array}{c}\text { Elevation } \\
(\mathrm{m})\end{array}$} & \multicolumn{2}{|c|}{ Y-direction $(\mathrm{mm})$} \\
\cline { 3 - 4 } & 12 & Timber & RCC \\
\hline Terrace & 24.85 & 75.42 \\
\hline $3^{\text {rd }}$ & 9 & 42.82 & 131.89 \\
\hline $2^{\text {nd }}$ & 6 & 55.76 & 172.94 \\
\hline $1^{\text {st }}$ & 3 & 65.43 & 202.75 \\
\hline Plinth & 0 & 66.02 & 206.44 \\
\hline
\end{tabular}

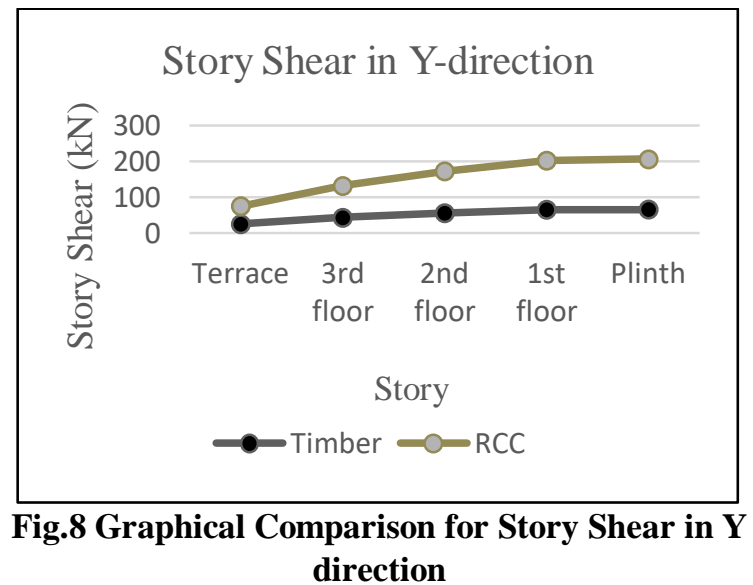

\section{CONCLUSIONS}

From the results discussed above with respect to the RCC and Timber buildings considered leads to the following conclusions:

i. It is observed that the shear force and bending moment decreases within the same section, due to decrease in modulus of elasticity of material. This results in lighter beams and columns in timber materials.

ii. The Lateral story displacement increases in timber buildings as compared to RCC buildings, due to less flexibility of RCC structures.

iii. Story shear comes out to be less in timber building than RCC building. The deficient stiffness of timber material in building can be achieved by providing strong connections at each joint, and also by providing rigid diaphragm action at each floor.

iv. The displacements in $\mathrm{X} \& \mathrm{Y}$ direction increases with the decrease in elasticity of material.

v. The Environmental impact of concrete creates suspicious doubts about its sustainability in the long term construction. So in India, there might be the need of such renewable material like timber to build multistory structures.

\section{REFERENCES}

1. Hailing Xing, Songtao Xuc and Gang Zong, [2011], "Dynamic Properties of Conventional Beam-Column Timber Structure Under Successive Damage", Journal of Asian Architecture and Building Engineering, May 2011, 202.

2. IS: 3629 - 1986, Specification for Structural Timber in Building (First revision), Bureau of Indian Standards, New Delhi, 1987.

3. The Institution of Structural Engineers (TRADA), [2007], Manual for the design of timber building structures to Eurocode 5.
4. Forest Products Laboratory (1999), Wood Handbook - Wood as an engineering material, Madison, WI: U.S. Department of Agriculture Forest Service, Forest Products Laboratory, 1999. 